\title{
ROLE OF THE CYP1A2 GENE POLYMORPHISM ON EARLY AGEING FROM OCCUPATIONAL EXPOSURE
}

\author{
Eshkoor SA ${ }^{1,2, *}$, Ismail $\mathrm{P}^{1}$, Rahman $\mathrm{SA}^{2}$, Moin $\mathrm{S}^{2}$, Adon $\mathrm{MY}^{3}$
}

\begin{abstract}
*Corresponding Author: Dr. Sima A. Eshkoor, Institute of Gerontology, Faculty of Medicine and Health Sciences, Universiti Putra Malaysia (UPM), 43400, Malaysia; Tel.: +60-129-797-812; Fax: +60-389-472-744; E-mail: simaataolahi@yahoo.com
\end{abstract}

\begin{abstract}
The ageing process is influenced by many internal and external factors. The toxic substances in the environment can cause genomic damages to cells, which increase the risk of early ageing. Furthermore, the cytochrome P450 1A2 (CYP1A2) gene polymorphism is a susceptibility factor and may enhance the risk of DNA damage in cells. The current study was carried out to show whether occupational exposure could cause genotoxicity in cells carrying the CYP1A2 gene polymorphism, thus enhancing the likelihood of early ageing. This study was conducted on mechanical workshop workers and a control group by collecting buccal cells from their mouths. Restriction fragment length polymorphism-polymerase chain reaction (RFLP-PCR) was used to identify the CYP1A2 gene polymorphism in the cells. In addition, three extra methods including micronuclei (MN) test, comet assay and real-time PCR (RT-PCR) were applied to determine the effects of gene polymorphisms on DNA damage and ageing from occupational exposure. The results showed that DNA damage in the cells carrying the mutated genotype was higher than the wild geno-
\end{abstract}

\footnotetext{
${ }^{1}$ Institute of Gerontology, Universiti Putra Malaysia (UPM), Serdang, Selangor, Malaysia

2 Department of Biomedical Sciences, Faculty of Medicine and Health Sciences, Universiti Putra Malaysia (UPM), Serdang, Selangor, Malaysia

${ }^{3}$ Institute for Medical Research, Ministry of Health Malaysia, Kuala Lumpur, Malaysia
}

type. In addition, the difference in MN frequency ( $p$ $=0.001)$ and relative telomere length $(p=0.002)$ between workers and controls was significant $(p<0.05)$ in the mutated genotype. The findings indicated a possible protective effect of gene polymorphism against early ageing, which was characterized by lack of a significant influence of CYP1A2 gene polymorphism on genetic material in the subjects $(p>0.05)$. It was concluded that the CYP1A2 gene could be a contributing factor to prevent early ageing from occupational exposure.

Keywords: Ageing; Buccal Cells; Cytochrome P450 (CYP), Cytochrome P450 1A2 (CYP1A2) gene polymorphism; Micronuclei (MN) test; Occupational exposure

\section{INTRODUCTION}

Ageing happens due to the accumulation of mutations in the genome of somatic cells. It results in tissue atrophy, development of neoplasia and decreased functions of cells and tissues [1]. A combination of both genetic and environmental factors can affect the process at the cellular level [2]. As ageing affects resistance against diseases and speeds up the end, new data and investigations suggest that the ageing process can be slowed down at the molecular and cellular level, thereby increasing ones' life-span [3].

Cytochrome P450 (CYP) enzymes are involved in phase I of xenobiotic metabolism to oxidize these compounds. Such enzymes can metabolically produce 
activated substances from chemicals that may act as highly reactive mutagenic metabolites [4]. There are specific forms of CYP450 enzymes that are major susceptibility biomarkers to activate mutagens and their activities associated with a variety of sociodemographic factors and genetic characteristics [5].

The cytochrome P450 1A2 (CYP1A2) gene polymorphism is one of CYP450 enzymes family involved in metabolic activation of many of chemicals. The reactive oxygen species (ROS) generated by the CYP1A2 enzyme activity can lead to the oxidative DNA damage and mutagenesis in cells. Apparently, the enzyme activity is an important tool to assess the risk of mutagenesis from chemical exposure. The polymorphism of the CYP1A2 gene can affect the levels of enzyme activity. The polymorphism type can cause a higher activity of enzyme from exposure to different environmental factors such as smoking and caffeine [6].

Using different molecular and cytogenetic techniques in various studies of toxicology helps to reflect the risk of exposure to mutagenic agents such as environmental and occupational exposures. In addition, biomarkers are used in the studies to evaluate exposure, effect and susceptibility in individuals. As a susceptibility biomarker, the CYP genetic polymorphism can affect the activation or inactivation of xenobiotics and determine the risk of DNA damage at the exposure to genotoxic agents. Such biomarkers, and the biomarkers of early biological effects, help to identify the risk of genome damage in cells [7]. These data can serve as an early warning to show the potential risk of health damage from long term chemical exposure. Thus, using biological parameters increased our ability to study the effects of exposure and determine the spectrum of DNA damage [8]. This study was carried out to identify whether occupational exposure had any effect on DNA damage in the cells carrying the CYP1A2 gene polymorphism that enhanced the risk of early ageing.

\section{MATERIALS AND METHODS}

Permission and approval for the study were obtained from the ethical committee of the Medical and Health Sciences Faculty, University Putra Malaysia (UPM), Ser-dang, Selangor, Malaysia [Reference Number: UPM/ FPSK/PADS/T7-MJKEtikaPer/F01 (JSB-Aug (08)05]. The samples were epithelial cells of buccal mucosa. For this project 120 mechanical workshop workers were selected. The exposed group included males aged 18 years and above. The considered duration time of working in the workshops was at least 1 year or more. Furthermore, 120 people who were not exposed to petrochemical products such as fruit sellers, textile shop keepers, sellers in mobile phone shops, restaurant workers, sundry shops workers, bank staff, photography shop workers, supermarket staff, workers in computer centers, electronic centers and optical examination centers, were selected as a control group. Subjects were interviewed about their health status, educational level, smoking habits, alcohol consumption, work history, duration of working at one occupation and other aspects relevant to the study. In addition, workers were divided into two groups, those with 5 or more years in one group and those with less than 5 years in another group.

Respondents were asked to rinse their mouth with water before collection of the buccal samples. The cells were collected by scraping the inner part of the cheeks both sides with a cytology brush. Then, the cells were gently mixed with $0.9 \%$ sodium chloride and phosphate buffered saline (PBS) in separate micro-centrifuge tubes and brought to the laboratory. The cells were treated for micronuclei (MN) test, comet assay, real-time polymerase chain reaction (RTPCR) and restriction fragment length polymorphism (RFLP). The effect of polymorphism on the samples was assessed by MN formation, comet tail length and telomere length shortening as the biological parameters. The methods of the MN test and comet assay were performed according to a pattern described in [9]. In the current study, genomic DNA was extracted from the cells using QIAamp DNA blood MiniKit (Qiagen, Courtaboeuf, France) and then was quantified by Nanodrop ${ }^{\mathrm{TM}} 1000$ spectrophotometer (Thermo Scientific, Wilmington, DE, USA). Meanwhile, the extracted DNA was run on a $0.7-1.0 \%$ agarose gel. Genomic DNA was used to run RT-PCR and RFLP.

Real-Time Polymerase Chain Reaction. In RTPCR, the reaction was performed to optimize primers and determine a suitable annealing temperature. The primers for telomere and 36B4 were those described in a prior study [10]. The appropriate annealing temperature for both primers was $56^{\circ} \mathrm{C}$. The primer sequences were: tell (5'-GGT TTT TGA GGG TGA GGG TGA GGG TGA GGG TGA GGG T-3'); tel2 (5'-TCC CGA CTA TCC CTA TCC CTA TCC CTA TCC CTA TCC 
CTA-3'); 36B4u (5'-CAG CAA GTG GGA AGG TGT AAT CC-3'); 36B4d (5'-CCC ATT CTA TCA TCA ACG GGT ACA A-3'). Real-time PCR improved the assessment of relative telomere length measurement. The telomere repeat copy number to single gene copy number (T:S) ratio was detected by using Corbett Rotor-Gene 6000 (Corbett Life Science, Sydney, New South Wales, Australia) in a 36-well format. The extracted DNA from buccal cells was used in the procedure. During the reaction, each sample was evaluated concurrently for both telomere and the housekeeping gene $36 B 4$. The primers were obtained from Bioline (London, UK). For each PCR reaction, a $25 \mu \mathrm{L}$ volume of solution was prepared in the PCR tube. The solution for the PCR reaction included 0.6 $\mu \mathrm{L}$ of each primer, $1 \mu \mathrm{L}$ of Eva green (Biotium, Hayward, CA, USA), $1 \mu \mathrm{L}$ of DNA, $5 \mu \mathrm{L}$ of master mix Immomix (Bioline), and $16.8 \mu \mathrm{L}$ of pure water. The reaction proceeded one cycle of denaturation at $94^{\circ} \mathrm{C}$ for $5 \mathrm{~min}$., followed by 40 cycles at $94^{\circ} \mathrm{C}$ for $30 \mathrm{sec}-$ onds, $56^{\circ} \mathrm{C}$ for 30 seconds, and $72^{\circ} \mathrm{C}$ for 50 seconds. The melting temperature was arranged between $70^{\circ} \mathrm{C}$ and $95^{\circ} \mathrm{C}$. Finally, the products were resolved in $2.0 \%$ gel to ensure amplification of the specific products. All samples were run in triplicate for both genes, and the threshold value was assessed. In addition, a serial dilution of genomic DNA derived from one sample was run to ensure having a good view of the efficiency of the PCR reaction standard curve. The obtained data from the samples were interpreted throughout the data set to assess the threshold cycle $(\mathrm{Ct})$ values. The $\mathrm{T}: \mathrm{S}$ ratio was calculated based on the fractional number between the average $36 \mathrm{~B} 4 \mathrm{Ct}$ value and the average telomere $\mathrm{Ct}$ value for each sample. One sample was used as reference in each run in triplicate for comparing the results. The formula $2^{-\Delta \Lambda}$ was used to calculate the $\mathrm{T} / \mathrm{S}$ ratio. For calculating, $\Delta \mathrm{C}_{\mathrm{T}}=\mathrm{C}_{\mathrm{t}}$ (telomere) $-\mathrm{C}_{\mathrm{t}}$ (36B4) formula was applied. Final calculation was based on the results of $\Delta C_{t}$ (target) $-\Delta C_{t}$ (reference) formula to compare the measurements and take proper $\mathrm{T}: \mathrm{S}$ ratio. Furthermore, the RFLP method was applied to identify the CYPIA2 gene polymorphism.

Polymerase Chain Reaction and Restriction Fragment Length Polymorphism CYP1A2. Polymerase chain reaction was performed to optimize primers and obtain proper annealing temperature by gradient PCR analysis. Primer sequences for CYP1A2 were: sense (5'-GCT ACA CAT GAT CGA GCT ATA C-3') and anti-sense (5'-CAG TCT CTT CAC TGT
AAA GTT A-3'). The forward and reverse primers were selected from the published article [11]. The solution volume in the PCR tube was $25 \mu \mathrm{L}$. Immomix master mix (Bioline) containing dNTPs, Taq polymerase, $\mathrm{MgCl}_{2}$ and a buffer were used for PCR reactions. To prepare the product, each tube received $5 \mu \mathrm{L}$ of immomix master mix, $0.6 \mu \mathrm{L}$ of primer, 2 to $6 \mu \mathrm{L}$ of genomic DNA and 12.8 to $16.8 \mu \mathrm{L}$ of pure water. The tubes were placed in a G-Storm Thermal Cycler (Gene Technology Ltd, Braintree, Essex, UK) for PCR reaction. The PCR was performed in $35 \mathrm{cy}-$ cles. The first cycle initiated by an incubation time at $94^{\circ} \mathrm{C}$ for $5 \mathrm{~min}$. The reaction was then followed by a denaturation step at $94^{\circ} \mathrm{C}$ for 30 seconds, annealing at $62^{\circ} \mathrm{C}$ for 30 seconds, extension phase at $72^{\circ} \mathrm{C}$ for 45 seconds and a final extension at $72^{\circ} \mathrm{C}$ for $10 \mathrm{~min}$. after the last cycle. After completing amplification, the samples were stored at $4^{\circ} \mathrm{C}$ until used. A negative control without a DNA template was carried out in every run. The specific PCR product was identified by running 1.8 to $2.0 \%$ agarose gel electrophoresis, and the gel was then viewed with an AlphaImager analysis system (Alpha Innotech, San Leandro, CA, USA). The product size was $596 \mathrm{bp}$.

Fifteen microlitres of $\mathrm{PCR}$ reaction product was put aside for RFLP. First, $7.3 \mu \mathrm{L}$ of double-distilled water $\left(\mathrm{ddH}_{2} \mathrm{O}\right)$ was added to the PCR tube, then 1.5 $\mu \mathrm{L}$ of restriction enzyme (RE) buffer, and then 6.0 $\mu \mathrm{L}$ of amplified PCR product. Finally, $0.2 \mu \mathrm{L}$ of each RE including Fast Digest $B s l \mathrm{I}$ and $D d e \mathrm{I} 10 \mathrm{U} / \mu \mathrm{L}$ was added to the tube. The mixture was mixed well by gently pipetting. The reaction mixture for each enzyme was prepared in the discrete tubes and then incubated on a heating block at $37^{\circ} \mathrm{C}$ for 16 hours. After incubation, $D d e$ I enzyme was inactivated by incubating at $65^{\circ} \mathrm{C}$ for $20 \mathrm{~min}$. on a heating block. Fast Digest $B s l$ enzyme inactivation could be done by phenol or chloroform extraction. The size of the products was then identified using agarose gel electrophoresis. The gels used for PCR and RFLP products were 2.0 and $4.0 \%$, respectively. Meanwhile, DNA ladders of 50 $\mathrm{bp}$ and $100 \mathrm{bp}$ (Bioline) were used to identify the size of the products. Finally, the gel was viewed under UV light using the AlphaImager ${ }^{\text {TM }} 2200$ (Alpha Innotech) system.

Statistical Analyses. All data were analyzed using the Statistical Package for the Social Sciences (SPSS, Chicago, IL, USA) software version 16.0. The statistical tests were independent $t$-test and the 
Mann-Whitney U-test. Micronuclei frequency and DNA damage tail length were tested using the non parametric Mann-Whitney U-test. The analysis method of the relative telomere length was the independent $t$-test. The Hardy-Weinberg equilibrium was evaluated by using the $\chi^{2}$ to test the rightness of the fit between adjusted samples. The critical level for rejection of the null hypothesis (two-tailed test) was the $p$ value of $5.0 \%(p=0.05)$.

\section{RESULTS}

The CYP1A2 gene polymorphism was amplified by PCR followed by the RFLP method using DdeI and $B s l$ restriction enzymes. Using both restriction enzymes helped to fix the determination of the CYP1A2 gene polymor-phisms. Figures 1, 2 and 3 show the images of PCR and RFLP products of the CYP1A2 gene. The $C Y P 1 A 2$ gene polymorphism was amplified by PCR and the product was $596 \mathrm{bp}$ (Figure 1).

The RFLP products resulting from the DdeI enzyme digestion were the wild (WW) and mutant (WM, $\mathrm{MM})$ genotypes. The size of the WW genotype was $596 \mathrm{bp}$; the fragment sizes for the heterozygous mutant (WM) genotypes were 596, 464 and $132 \mathrm{bp}$, and for

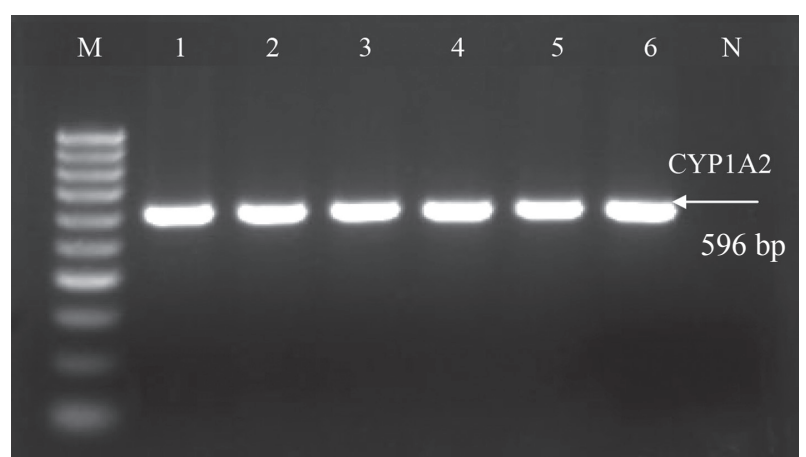

Figure 1. Amplification of the CYP1A2 PCR in 2.0\% agarose gel electrophoresis in lanes 1 through 6; $\mathrm{M}$ represents the $100 \mathrm{bp}$ DNA ladder; $\mathrm{N}$ is a negative control during the PCR reaction.

homozygous mutant (MM) genotypes were 464 and $132 \mathrm{bp}$ (Figure 2). The RFLP products after digestion with the BsII enzymes were MM (475 and 121 bp), MW $(475,343,132$ and $121 \mathrm{bp})$ and WW (343, 132 and 121 bp) genotypes (Figure 3). The RFLP products of CYP1A2 using the DdeI enzyme digestion were referred as the wild and mutated genotypes. The WW genotype was placed in the wild group and WM and MM were in the mutated group. The respective frequencies of the WW, WM and MM genotypes were 49.2, 46.3 and 4.6\%

Table 1. Effect of the CYP1A2 genotypes on the biomarkers in the individuals.

\begin{tabular}{|l|c|c|c|c|}
\hline Biomarkers & & MN & Comet Tail Length & Relative Telomere Length \\
\hline CYP1A2 Genotypes & $\boldsymbol{n}$ & $\boldsymbol{p}$ Value & $\boldsymbol{p}$ Value & $\boldsymbol{p}$ Value \\
\hline WW & 118 & 0.272 & 0.122 & 0.287 \\
\hline MW, MM & 122 & 0.272 & 0.122 & 0.287 \\
\hline
\end{tabular}

MN: Micronuclei; WW: wild genotype; MW: heterozygous mutant genotype; MM: homozygous mutant genotype.

The Mann-Whitney U-test was used for DNA damage and MN and the independent $t$-test for telomere length $(p=0.05)$.

Table 2. The CYP1A2 genotype effects on the biomarkers between the workers and controls.

\begin{tabular}{|l|l|c|r|c|c|c|c|c|}
\hline \multirow{2}{*}{ Genotypes } & & $n$ & \multicolumn{2}{|c|}{ MN } & \multicolumn{2}{c|}{ Comet Tail Length } & \multicolumn{2}{c|}{ Relative Telomere Length } \\
\hline \multirow{2}{*}{ WW } & & & Mean \pm SD & $p$ Value & Mean \pm SD & $p$ Value & Mean \pm SD & $p$ Value \\
\hline \multirow{2}{*}{ MW, MM } & Workers & 58 & $11.66 \pm 4.31$ & & $23.70 \pm 8.59$ & & $0.23 \pm 0.37$ & \\
& Controls & 60 & $2.38 \pm 4.31$ & 0.001 & $17.14 \pm 7.81$ & 0.089 & $1.68 \pm 7.02$ & 0.114 \\
& Workers & 62 & $12.89 \pm 4.38$ & & $26.46 \pm 9.01$ & & $0.32 \pm 0.72$ & \\
\end{tabular}

MN: Micronuclei; WW: wild genotype; MW: heterozygous mutant genotype; MM: homozygous mutant genotype.

The Mann-Whitney U-test was used for DNA damage and MN and the independent $t$-test for telomere length $(p=0.05)$. 


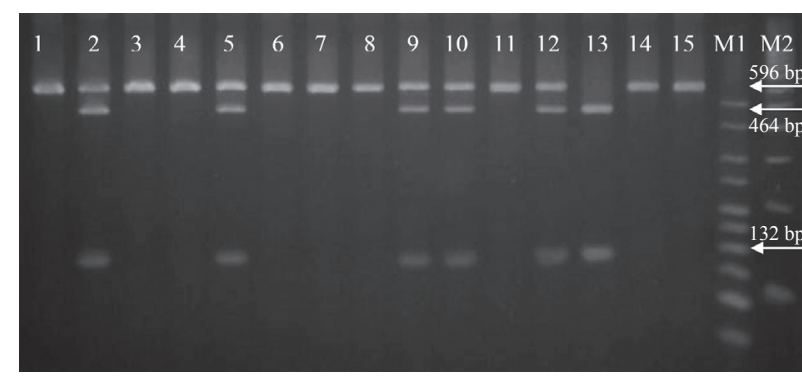

Figure 2. Restriction fragments of the CYP1A2 gene with the DdeI enzyme resolved in $4.0 \%$ agarose gel electrophoresis in lanes 1 through 15; M1 and M2 represent the 50 and 100 bp DNA ladders, respectively.

in all individuals. Furthermore, the results showed that the gene polymorphism did not significantly influence $(p>0.05)$ the individual biomarkers (Table 1).

Differences in biomarkers between workers and controls was evaluated in wild (WW) and mutated (WM and MM) genotypes. It was found that difference in $\mathrm{MN}$ frequency between workers and controls was statistically significant in both wild $(p=0.001)$ and mutated $(p=0.001)$ genotypes. In addition, the results showed that the mutated genotype significantly affected the relative telo-mere lengths $(p=0.002)$ in workers. No statistically significant effect on comet tail length $(p>0.05)$ was found in wild or mutated genotypes (Table 2).

The results showed that the gene polymorphism had no significant effects on the biomarkers in workers and control groups below 30 years old or above. However, the wild genotype significantly affected comet tail length in workers below 30 years of age ( $p$ $=0.047$ ) (Table 3 ). The findings of socio-demographic factors indicated that ethnicity had a significant effect on $\mathrm{MN}$ frequency $(p=0.004)$. Furthermore, duration time of 5 years or more significantly affected MN frequency $(p=0.001)$, comet tail length $(p=0.001)$ and relative telomere length $(p=0.001)$. It was found that smoking, alcohol consumption and educational levels showed no statistically significant effect on each of the biomarkers $(p>0.05)$.

\section{DISCUSSION}

DNA damage can occur due to the effects of the CYP1A2 gene and environmental factors [12]. The subjects showed a shorter telomere length on the mu-

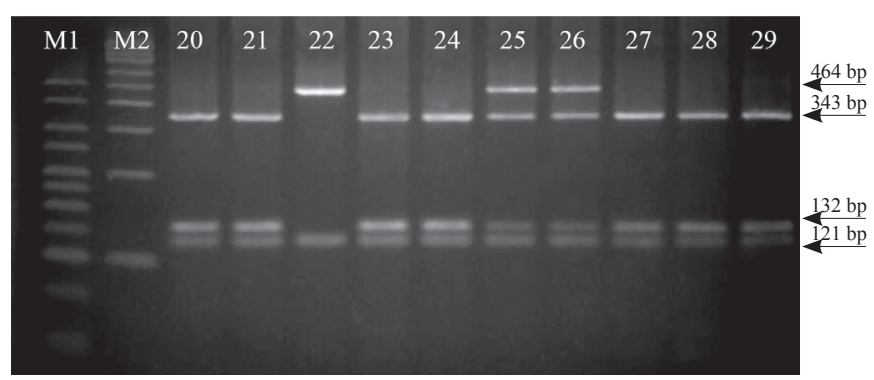

Figure 3. Restriction fragments of the $C Y P 1 A 2$ gene with the $B s l$ I enzyme resolved in $4.0 \%$ agarose gel electrophoresis in lanes 20 through 29; M1 and M2 represent the 50 and 100 bp DNA ladders, respectively.

tated genotype yet a higher MN frequency in both wild and mutated genotypes. Such effects suggest the possible influence of gene polymorphism on DNA damage mediation in the cells [13], which could be due to the increased enzyme activity as well as sensitivity of cells to genotoxic effects [12]. Despite the paradoxical reports, our result confirmed a correlation between the different genotypes and MN frequency [14]. Such correlation is probably due to more sensitivity of MN than the other biomarkers to express the effects of genotypes on genetic material damage from occupational exposure. Contrary to previous reports indicating DNA damage in the cells $[5,6,15]$, no statistically significant influence was observed on comet tail length in our research either in wild or mutated genotypes.

In the current study, age did not contribute to enhance the influence of the CYP1A2 gene presenting in higher $\mathrm{MN}$, shorter telomere length and greater comet tail length in workers and controls, except greater comet tail length in the younger group of workers. Lack of age effects suggest a protection effect of gene against ageing. Apparently, the $C Y P 1 A 2$ gene prevents the modulation of DNA damage [16-18] by transcriptional activation and resistance to changes, which can be interfered with lifestyle factors [19,20], different genotypes and genes interactions [21].

Among all lifestyle factors, only ethnicity significantly affected $\mathrm{MN}$ frequency regardless of occupational exposure, which indicates the possible influence of gene polymorphism on the cell protection against genome damage [22]. Meanwhile, this research was a confirmation of the studies [23,24] indicating the association of DNA damage with working duration time. It seems that good interpretation of results 
Table 3. The CYP1A2 gene polymorphism and age effects on the biomarkers between the mutated and wild genotypes in the worker and control groups.

\begin{tabular}{|c|c|c|c|c|c|c|c|c|c|}
\hline \multirow[t]{2}{*}{ Groups } & \multirow[b]{2}{*}{ Age } & \multirow[b]{2}{*}{ Genotypes } & \multirow[b]{2}{*}{$n$} & \multicolumn{2}{|c|}{ MN } & \multicolumn{2}{|c|}{ Comet Tail Length } & \multicolumn{2}{|c|}{ Relative Telomere Length } \\
\hline & & & & Mean \pm SD & $p$ Value & Mean \pm SD & $p$ Value & Mean \pm SD & $p$ Value \\
\hline Workers & $\begin{array}{l}>30 \\
\text { years }\end{array}$ & $\begin{array}{l}\text { WW } \\
\text { MW, MM }\end{array}$ & $\begin{array}{l}23 \\
31\end{array}$ & $\begin{array}{l}15.77 \pm 3.33 \\
15.48 \pm 3.82\end{array}$ & 0.909 & $\begin{array}{l}31.86 \pm 6.04 \\
31.07 \pm 8.54\end{array}$ & 0.535 & $\begin{array}{l}0.03 \pm 0.03 \\
0.03 \pm 0.02\end{array}$ & 0.939 \\
\hline Workers & $\begin{array}{c}<30 \\
\text { years }\end{array}$ & $\begin{array}{l}\text { WW } \\
\text { MW, MM }\end{array}$ & $\begin{array}{l}35 \\
31\end{array}$ & $\begin{array}{c}8.95 \pm 2.23 \\
10.30 \pm 3.06\end{array}$ & 0.074 & $\begin{array}{l}18.34 \pm 5.03 \\
21.85 \pm 6.94\end{array}$ & 0.047 & $\begin{array}{l}0.36 \pm 0.43 \\
0.62 \pm 0.93\end{array}$ & 0.166 \\
\hline $\begin{array}{l}\text { Total } \\
\text { Workers }\end{array}$ & $\begin{array}{c}\text { All } \\
\text { ages }\end{array}$ & $\begin{array}{l}\text { WW } \\
\text { MW, MM }\end{array}$ & $\begin{array}{l}58 \\
62\end{array}$ & $\begin{array}{l}11.66 \pm 4.31 \\
12.89 \pm 4.32\end{array}$ & 0.116 & $\begin{array}{l}23.70 \pm 8.59 \\
26.46 \pm 9.01\end{array}$ & 0.102 & $\begin{array}{l}0.23 \pm 0.37 \\
0.32 \pm 0.72\end{array}$ & 0.373 \\
\hline Controls & $\begin{array}{l}>30 \\
\text { years }\end{array}$ & $\begin{array}{l}\text { WW } \\
\text { MW, MM }\end{array}$ & $\begin{array}{l}5 \\
6\end{array}$ & $\begin{array}{l}6.07 \pm 1.90 \\
6.78 \pm 2.25\end{array}$ & 0.537 & $\begin{array}{l}29.29 \pm 3.96 \\
26.76 \pm 6.33\end{array}$ & 0.537 & $\begin{array}{l}1.39 \pm 1.36 \\
1.35 \pm 2.85\end{array}$ & 0.976 \\
\hline Controls & $\begin{array}{c}<30 \\
\text { years }\end{array}$ & $\begin{array}{l}\text { WW } \\
\text { MW, MM }\end{array}$ & $\begin{array}{l}55 \\
54 \\
\end{array}$ & $\begin{array}{l}2.04 \pm 1.38 \\
2.04 \pm 1.01\end{array}$ & 0.583 & $\begin{array}{l}16.03 \pm 7.11 \\
16.83 \pm 7.86\end{array}$ & 0.565 & $\begin{array}{l}1.71 \pm 7.33 \\
3.16 \pm 6.43\end{array}$ & 0.275 \\
\hline $\begin{array}{l}\text { Total } \\
\text { Controls }\end{array}$ & $\begin{array}{c}\text { All } \\
\text { ages }\end{array}$ & $\begin{array}{l}\text { WW } \\
\text { MW, MM }\end{array}$ & $\begin{array}{l}60 \\
60\end{array}$ & $\begin{array}{l}2.38 \pm 1.80 \\
2.50 \pm 1.85\end{array}$ & 0.543 & $\begin{array}{l}17.14 \pm 7.81 \\
17.82 \pm 8.24\end{array}$ & 0.607 & $\begin{array}{l}1.68 \pm 7.02 \\
2.98 \pm 6.17\end{array}$ & 0.286 \\
\hline
\end{tabular}

MN: Micronuclei; WW: wild genotype; MW: heterozygous mutant genotype; MM: homozygous mutant genotype.

The Mann-Whitney U-test was used for DNA damage and MN and the independent $t$-test for telomere length $(p=0.05)$.

depends on a suitable sample size in each group of various genotypes and age. However, the study was cross-sectional, therefore, finding effective and non effective factors were difficult. Another limitation of the study was the difficulty of determining and isolating the exact effects of gene polymorphisms. Despite the above limitations, this study can serve as a base to address the effects of these genotypes and surrounding risk factors on early ageing. Accordingly, CYP1A2 genotypes contributed to DNA damage from occupational exposure, hence, further investigations are needed to evaluate the exact effects of different genotypes on a subject's premature aging.

\section{ACKNOWLEDGMENTS}

The authors gratefully acknowledge the cooperation of all volunteers who participated in this study.

Declaration of Interest: The authors report no conflicts of interest. The authors alone are responsible for the content and writing of this article.

\section{REFERENCES}

1. Vijg J. Somatic mutations and aging: a re-evaluation. Mutat Res. 2000; 447(1): 117-135.
2. Wojda A, Witt M. Manifestations of aging at the cytogenetic level. J Appl Genet. 2003; 44(3): 383-399.

3. Harman D. The aging process: major risk factor for disease and death. Proc Nat Acad Sci USA. 1991; 88(12): 5360-5363.

4. Pande M, Amos CI, Osterwisch DR, Chen J, Lynch PM, Broaddus R, et al. Genetic variation in genes for the xenobiotic-metabolizing enzymes CYP1A1, EPHX1, GSTM1, GSTT1, and GSTP1 and susceptibility to colo-rectal cancer in Lynch Syndrome. Cancer Epidemiol Bio-markers Prev. 2008; 17(9): 2393-2399.

5. Lautraite S, Musonda AC, Doehmer J, Edwards GO, Chipman JK. Flavonoids inhibit genetic toxicity produced by carcinogens in cells expressing CYP1A2 and CYP1A1. Mutagenesis. 2002; 17(1): 45-53.

6. Al Zabadi H, Ferrari L, Laurent AM, Tiberguent A, Paris C, Zmirou-Navier D. Biomonitoring of complex occupational exposures to carcinogens: the case of sewage workers in Paris. BMC Cancer. 2008; 8(1): 67-77.

7. Vainio $\mathrm{H}$. Use of biomarkers in risk assessment. Int J Hyg Environ Health. 2001; 204(2-3): 91-102. 
8. Martino-Roth MG, Viegas J, Amaral M, Oliveira L, Ferreira FLS, Erdtmann B. Evaluation of genotoxicity through micronuclei test in workers of car and battery repair garages. Genet Mol Biol. 2002; 25(4): 495-500.

9. Eshkoor SA, Ismail P, Rahman SA, Moin S. Does GSTP1 polymorphism contribute to genetic damage caused by ageing and occupational exposure? Arh Hig Rada Toksikol. 2011; 62(4): 291-298.

10. Cawthon RM. Telomere measurement by quantitative PCR. Nucleic Acids Res. 2002; 30(10): e47.

11. Nakajima M, Yokoi T, Mizutani M, Kinoshita M, Funayama M, Kamataki T. Genetic polymorphism in the 5'-flanking region of human CYP1A2 gene: effect on the CYP1A2 inducibility in humans. J Biochem. 1999; 125(4): 803-808.

12. Pavanello S, Pulliero A, Lupi S, Gregorio P, Clonfero E. Influence of the genetic polymorphism in the 5'-noncoding region of the CYP1A2 gene on CYP1A2 phenotype and urinary mutagenicity in smokers. Mutat Res. 2005; 587(1-2): 59-66.

13. Hashizumea T, Yoshitomia S, Asahia S, Matsumuraa $\mathrm{S}$, Chatania $\mathrm{F}$, Odab $\mathrm{H}$. In vitro micronucleus test in $\mathrm{HepG} 2$ transformants expressing a series of human cyto-chrome $\mathrm{P} 450$ isoforms with chemicals requiring metabolic activation. Mutat Res. 2009; 677(1-2): 1-7.

14. da Silva J, Moraes CR, Heuser VD, Andrade VM, Silva FR, Kvitko K, et al. Evaluation of genetic damage in a Brazilian population occupationally exposed to pesticides and its correlation with polymorphisms in metabolizing genes. Mutagenesis. 2008; 23(5): 415-422.

15. Castorena-Torres F, Mendoza-Cantu A, de Leon MB, Cisneros B, Zapata-Perez O, López-Carrillo $\mathrm{L}$, et al. CYP1A2 phenotype and genotype in a population from the carboniferous region of Coahuila, Mexico. Toxicol Lett. 2005; 156(3): 331-339.

16. Bageman $E$, Ingvar $C$, Rose $C$, Jernstrom $H$. Coffee consumption and CYP1A2*1F genotype modify age at breast cancer diagnosis and estrogen receptor status. Cancer Epidemiol Biomarkers Prev. 2008; 17(4): 895-901.

17. Iba MM, Fung J. Pulmonary CYP1A1 and CY$\mathrm{P} 1 \mathrm{~A} 2$ levels and activities in adult male and female offspring of rats exposed during gestation and lactation to 2,3,7,8-tetrachlorodibenzo-p-dioxin. Biochem Pharmacol. 2001; 62(5): 617-626.

18. Sata F, Yamada H, Suzuki K, Saijo Y, Kato EH, Morikawa M, et al. Caffeine intake, CYP1A2 polymorphism and the risk of recurrent pregnancy loss. Mol Hum Reprod. 2005; 11(5): 357-360.

19. Kirsch-Volders M, Mateuca RA, Roelants M, Tremp A, Zeiger E, Bonassi S, et al. The effects of GSTM1 and GSTT1 polymorphisms on micronucleus frequencies in human lymphocytes in vivo. Cancer Epi-demiol Biomarkers Prev. 2006; 15(5): 1038-1042.

20. Garte S, Taioli E, Popov T, Kalina I, Sram R, Farmer P. Role of GSTT1 deletion in DNA oxidative damage by exposure to polycyclic aromatic hydrocarbons in humans. Int J Cancer. 2006; 120(11): 2499-2503.

21. Palma S, Cornetta T, Padua L, Cozzi R, Appolloni $\mathrm{M}$, Ievoli $\mathrm{E}$, et al. Influence of glutathione S-transferase polymorphisms on genotoxic effects induced by tobacco smoke. Mutat Res. 2007; 633(1): 1-12.

22. Zhan P, Wang J, Zhang Y, Qiu LX, Zhao SF, Qian $\mathrm{Q}$, et al. CYP2E1 Rsa I/Pst I polymorphism is associated with lung cancer risk among Asians. Lung Cancer. 2010; 69(1): 19-25.

23. Pinto D, Ceballos JM, Garcia G, Guzman P, Del Razo LM, Vera E, et al. Increased cytogenetic damage in outdoor painters. Mutat Res. 2000; 467(2): 105-111.

24. Manikantan P, Balachandar V, Sasikala K. DNA Damage in workers occupationally exposed to lead, using comet assay. Int J Biol. 2010; 2(1): 103-110. 
